\title{
Implementation of Early Childhood Character Education in the 2013 Curriculum
}

\author{
Susilawati ${ }^{1}{ }^{*}$, Erny Wahdini ${ }^{1}$, Sutarto Hadi 2 \\ ${ }^{1}$ Master Program of Early Childhood Teacher Education, Universitas Lambung Mangkurat, Banjarmasin \\ 70123, Indonesia \\ 2 Department of Mathematics Education, Universitas Lambung Mangkurat, Banjarmasin 70123, Indonesia
}

Article history:

Submission November 2019

Revised April 2020

Accepted April 2020

*Corresponding author:

E-mail: suzybarabai@gmail.com

\begin{abstract}
The purpose of this study is to describe the 2013 Curriculum in the (1) implementation of character education, (2) values, and (3) education strategy. Early Childhood Education is a form of education fundamental in the life of a child. In the 2013 Curriculum perspective, character education in early childhood integrated in Core Competencies 1 Spiritual Attitudes and Core Competencies 2 Social Attitudes. This study uses a descriptive qualitative approach to design multiple sites with data collected through interviews, observation, and documentation. This research uses a descriptive qualitative approach with a multi-site study design in the PAUD Islamic Integrated Al Khair Barabai and PAUD Negeri Pembina Barabai. Data collection techniques collected through interviews, observation, and documentation. To validate data using triangulation of sources, techniques, and time. The conclusion of the research is the 2013 curriculum is a source reference in the preparation of programmed activities and habituation activities in addition to the curriculum characteristic of the institutions of each institution. The character values implemented are 18 from the government, Spiritual Attitudes and Social Attitudes. The character education strategy is carried out by the Foundation, the head, educators, educational staff, students, parents who are used through planning, implementation and evaluation.
\end{abstract}

Keywords: Character education, PAUD, 2013 curriculum

\section{Introduction}

Civilization tends to decline in a community when it's moral, honor, and character demoralizes. These factors are responsible to obtain an orderly, safe, and prosperous society. Character education saves the decline of the moral values of Pancasila and shapes one's personality as seen in a person's actions, towards good words and deeds.

According to Lickona, the quality of the character of a society is characterized by the quality of the character of its young generation, which can be an important indicator of whether a nation can progress or not. Lickona identified 10 signs of the character of the young generation that are worth worrying about because it will make a nation sink into ruin. The ten signs are; (1) Increased violence among adolescents, (2) worsening use of language and words, (3) Strong peer-group influence in acts of violence, (4) Increased self-destructive behavior, such as drug use, alcohol, and free sex, (5) Increasingly obscured good and bad moral guidelines, (6) Declining work ethic, (7) Declining respect for parents and teachers, (8) Low sense of individual and citizen responsibility, (9) Cultivating dishonesty, and (10) There are mutual suspicion and hatred between people (Megawangi, 2017).

The increasing level of drug users is also one of the problems of the Indonesian people. How much effort the government has done to 
socialize early on, arrest drug dealers and tighten border guarding that is prone to drug distribution. Various alternatives to overcome the moral crisis or character have carried out by the government and stakeholders, such as making laws and regulations, increasing the implementation, and law enforcement efforts. Besides that, to overcome moral or character crises is to carry out character education at every level of education. Every level of education is expected to create a conducive atmosphere in the application of character education, which is by involving all components of education both institutions, families, communities, and related government.

Character education is one of the choices to overcome the moral degradation of the Indonesian nation at every age, especially in early childhood. The implementation of character education in Indonesia is not only at age Elementary Schools to Colleges but from an early age, i.e. implemented in Informal Education or Family Education and non-formal education especially in Non-formal Early Childhood Education Institutions. Early Childhood Education is a fundamental form of education in the life of a child and education at this time will determine the survival of the child itself also for a nation. Character education at an early age can follow a certain pattern, namely an organized behavior, discipline, and standard or according to standards (Sudaryanti, 2012)

PAUD is a fundamental form of education in a child's life which is highly strategic in instilling positive character values. Schools as educational institutions play an important role in the development of skills, character, attitudes, and teaching science to children (Ahmad, 2014). The character formation will be determined not only by the strength of management in the relevant organizational units of the school. The strength of management is very dependent on the quality and strength of the principal as a leader (Suriansyah, 2015).

PAUD is the most fundamental education because child development in the future is largely determined by various meaningful stimulations given from an early age. Early childhood education must be planned in a holistic and integrated manner so that in the golden period the development of the child gets full stimulation, to develop his various potentials. Efforts can be made to develop this potential through a structured education program. The component for structured education is the curriculum. The curriculum is defined as an educational design that outlines all learning experiences provided for students). In the study of philosophy, its values, and knowledge are integrated with educational actions (Suhaimi \& Rinawati, 2018).

In 2013 the Curriculum of PAUD covered all aspects of development including attitude, religious, moral, physical, cognitive, and emotional values. Furthermore, it structured the development of Core Competencies which comprises of spiritual and social attitudes. Educational success is determined by the foundation in learning and its elements such as students, educators, interaction, environment, and educational content (Salaisiah, Asniwati \& Effendi, 2018).

PAUD Islam Terpadu Al Khair Barabai is an early childhood education institution which is in great demand by parents. This is proven from a large number of students irrespective of the exorbitant tuition fees. However, parents testified that they are often reminded by their children when they behave contrary to the behaviors taught in PAUD institutions. For example, when parents eat or drink while standing, their children automatically reprimand them by reading the hadith related to its prohibition. Negeri Pembina Barabai is an early childhood education institution which is not popular in the city of Barabai. Also, it is a public school, affordable by parents and graduates emerge with outstanding character and readiness to further their education to other levels.

Based on the description above, the researchers chose PAUD Islam Terpadu Al Khair Barabai and PAUD Negeri Pembina Barabai as the study location. The purpose of this research is to determine and describe the: (1) Implementation of the 2013 curriculum in character education, (2) Character values, and (3) the Strategies in both locations.

\section{Material and Methods}

This study uses a qualitative descriptive approach with multi-site research design and 
data collection techniques through interviews, observation, and documentation. Research time for one year. Data were analyzed from the process of research in the field carried out until the end of data collection using data analysis techniques proposed by Miles, Huberman \& Huberman (2014).

The objects of observation consist of educators, staff, students, parents, and learning activities. The object of the interview is related to how the implementation of the 2013 Curriculum in character education, is implemented, and the strategy involved (Metroyadi, 2017). Observations were carried out directly by observing the learning process at the PAUD Islam Terpadu Al Khair Barabai and Negeri Pembina Barabai with the habituation and behavior of all components including facilities and infrastructure. Furthermore, the Weekly Learning Implementation Plan (RPPM), (Daily learning implementation plan) RPPH, Standard Operating Procedures (SOP), institutional profile, vision, mission, goals of the institution, administrative structure, photo of activities, and other

Table 1: Comparison of Findings from Site 1 and Site 2 books are used to support character education (Sugiyono, 2017). Figure analyzes the CrossSite Data Analysis used in this study.

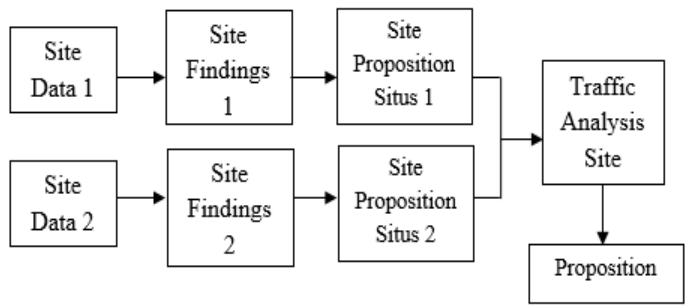

Figure 1. Cross-Site Data Analysis

\section{Results and Discussion}

This research was carried out at Terpadu Al Khair Barabai and Negeri Pembina Barabai based on a permit letter obtained from the Head of the Education Study Program of Early Childhood at Universitas Lambung Mangkurat Number: 059 / UN8.1.2.6.5 / SP on 31 August 2018. The data obtained from both institutions were compared in table 1 as follows:

\section{No. Research Focus}

1. How is the implementation of the 2013 curriculum in character education in the PAUD Islam Terpadu Al Khair Barabai and the Negeri Pembina Barabai?

\section{Data of Site 1}

\section{Data of Site 2}

Programmed Activities

a. RPPM: Core Competencies (KI), Base competencies (KD) of 2013 Curriculum, Graduate Competency Standard of the Integrated Islamic School Network (SKL of JSIT)

b. RPPH: 5M, TERPADU

Habituation Activities

a. Routine Activities: SOP, Liaison Book, Habituation Book, Memorandum Syllabus

b. Spontaneous Activities: reminding students, giving appreciation

c. Exemplary: from educators and teachers

d. Conditioning: spatial planning, Muslim dress and, non-smoking area banners
Programmed Activities

a. RPPM: KI, KD of 2013

Curriculum, SKL of JSIT

b. RPPH: $5 \mathrm{M}$

Habituation Activities

a. Routine Activities: SOP, Liaison Book

b. Spontaneous Activities: reminding students, giving appreciation

c. Exemplary: from educators and teachers

d. Conditioning: inside and outside spatial planning 
2. How is the character value implemented in the 2013 curriculum perspective in Islam Terpadu $\mathrm{Al}$ Khair Barabai and Negeri

Pembina Barabai?
3. How is the strategy of implementing character education in the 2013 curriculum in the PAUD Islam Terpadu Al Khair Barabai and Negeri

Pembina Barabai? e. Institutional Culture: SOP for education staff, $5 \mathrm{~S}$, and routine studies

a. JSIT: Faith and piety, manners, love of God, Apostles, Prophets, Companions, Prophet, Pillars of Faith, and Islam.

b. 18 character values: religious, honest, tolerance, discipline, hard work, creative, independent, democratic, curiosity, national spirit, love of the motherland, respect for achievement, friendly/communicative, love, peace, care for the environment, and society.

c. KI-1 Spiritual Attitude: observance of worship, gratitude, praying before and after activities, tolerance in worship. KI-2 Social Attitudes: honest, discipline, responsible, polite, caring, confident, cooperation, accuracy, perseverance, etc.

Character education is carried out by all teaching and education staff including students and parents. The strategies used are planning, implementation, and evaluation. e. Institutional Culture: $5 \mathrm{~S}$

a. 18 character values: religious, honest, tolerance, discipline, hard work, creativity, independent, democratic, curiosity, national spirit, love of the motherland, respect for achievement, friendly/ communicative, peace, love to read, and care for the environment.

b. KI-1 Spiritual Attitude: observance of worship, gratitude, praying before and after activities, tolerance in worship. KI-2 Social Attitudes: honest, discipline, responsible, polite, caring, confident, cooperation, accuracy, perseverance, etc.

Character education is carried out by all teaching and education staff including students and parents. The strategy used is planning, implementation, and evaluation.

\section{Implementation of the 2013 curriculum in character education}

The implementation of character education on sites 1 and 2 is carried out through the 2013 Curriculum which is integrated with the form of programmed and habituation activities. The programmed activities include RPPM and
RPPH. While in the habituation activities, it is carried out in the form of routine, spontaneous, exemplary, conditioning, and institutional culture. What distinguishes the two institutions is the existence of a unique curriculum in the form of a Graduate Competency Standard (SKL) from JSIT. 
The implementation of character values for young children is carried out through programmed and habituated activities, which are activities that are on the agenda and are designed in the syllabus of educators and learning tools, both in the short and long term, while habituation is an activity carried out through routine, spontaneous, exemplary activities, conditioning, and institutional culture.

On-site 1, the typical curriculum programmed activities are called the Graduate Competency Standard (SKL) of the Integrated Islamic School Network (JSIT) which are integrated through Basic Competencies (KD) and the learning process listed in the RPPH known asTERPADU. Therefore, in addition to containing the $5 \mathrm{M}$ component which consists of observation, asking, gathering information, reasoning, and communicating, it also contains a TERPADU component which comprises an explanation, exploration, response, habituation, affirmation, worldly and ukhrawi. Furthermore, habituation activities include routine, spontaneous, exemplary, conditioning, and institutional culture.

According to (Arsyad, 2010) character education can also be a hidden curriculum, such as time management, ethics, and integrity, thinking ability, willingness to learn, commitment, desire for success/motivation, strong energy impulse / very high spirit, oral communication, creativity, analytical skills, can deal with stress, self-management and take responsibility, problem-solving, cooperation, adaptability and wisdom, teamwork, ability to be a good listener.

Based on observations and interviews supported by documentation, it is obtained an overview of how the teacher's strategy in integrating character education in each learning, even outside of learning as done by the teacher in carrying out learning in the classroom and outside the class always shows the appropriate attitudes, behaviors, and actions with the norms that apply in schools and society consistently. At the exemplary point, the teacher needs to carry out activities for the class, by giving examples and improving learning outcomes for the proper developments of religious and moral values to help distinguish between good and bad actions. The use of audio-visual media tends to improve the development results of children's religious and moral values. Therefore, to create active and enjoyable learning, the quality of learning outcomes needs to be improved (Metroyadi, 2017).

In this habituation, site 1 uses the Customization Book and Memorandum Syllabus, to structure a variety of banners which supports the planting of the character and culture with the existence of SOPs and routine compulsory studies for each teaching and education staff. While site 2, uses the 2013 Curriculum as a reference in the preparation of learning activities programs.

\section{Character values implemented in the 2013 curriculum perspective}

Character values are applied based on Spiritual Attitude which consists of observance of worship, gratitude, praying before and after activities, tolerance in worship, as well as Social Attitude which consists of honest, discipline, responsibility, courtesy, care, confidence, cooperation, accuracy, and perseverance in the development of cultural education. Similarly, the national character made by the Ministry of National Education consists of religious, honest, tolerance, discipline, hard work, creative, independent, democratic, curiosity, the spirit of nationalism, love for motherland, respect for achievement, friendly communication, peace, love to read, care for the environment, and social responsibility. However, there are more character values which are applied on site 1, besides those mentioned above from the SKL of JSIT such as Faith and God-fearing, manners, love of God, Prophet, Companions, as well as, Pillars of Faith and Islam.

From the explanation above, it can be concluded that the inculcation of character values that are first accustomed to learners are religious character values such as daily Islamic etiquette such as eating and drinking etiquette, speaking etiquette, courtesy to dressing, courtesy of dressing, sleeping decency, eternity towards others, eternity towards parents, manner towards Allah's creations such as plants and animals through memorization of hadith, prayer, and short suras. This has a very significant impact on the character of students because it is done repeatedly every day so that it 
is formed into positive habits that become awareness for students and can reprimand others when they are not following the characters that have been taught and familiarized.

As the results of the study (Safutri, et al., 2018) which with one of the variables in the development of children's independence through the practical method of direct activities which shows the results of research that learning activities to develop children's independence through direct practice methods have been implemented well so that the average class reaches very active and classic criteria are in the very active category. Therefore, it is very important to use hands-on methods so that children are actively involved and gain direct experience through exemplary examples of the environment around children so that children can be able to follow them. Because one's success is determined by $20 \%$ of his hard skills and $80 \%$ percent of his soft skills. Following what was said by (Sukriani et al., 2017) that the quality of education has been largely determined by the character of students. Therefore, the focus on character development must be prioritized.

\section{Strategies for implementing character edu- cation in the 2013 curriculum perspective}

Education in the perspective of the national education system forms a whole person, that is, a person who is both character and intelligent (Suriansyah, 2015). Education in the perspective of the national education system forms a whole person, that is, a person who is both character and intelligence. The creation of quality education requires teachers and professional education staff with the hope of producing graduates who have a strong character, respecting cultural diversity as the glue of national integration, accompanied by mastery of basic life skills (soft skills) and the foundation of mastery of science and technology (hard skills) that necessary for their duties as individuals in society, upholding ethical values and being responsible for the welfare of the nation and the motherland (Brandsford \& Darling, 2005; Gardner, 2006). Character education needs to be done by all educators and education personnel as well as the involvement of parents which is very important because the strategy is part of the planning, while planning is part of success. This strategy is not only implemented in PAUD institutions but must involve the participation of parents so that education is not only the responsibility of the institution but must continue at home to create synergy and cooperation between educational institutions and parents in the education process of students.

Character education at sites 1 and 2 was carried out by all teaching and educational staff including the head, staff, students, and parents, through planning, implementation, and evaluation.

The development of attitude competence as well as the development of other competencies must be planned and implemented as thoroughly as possible so that the attitude that is built-in children is as expected. The development of a well-planned attitude competency will encourage the formation of character from an early age.

The principles that need to be considered in developing planning are: (1) The competency formulation in teaching preparation needs to be clear. The more concrete it is, the easier it is observed and the more precise the activities that need to be carried out to shape the competency. (2) Teaching preparation needs to be simple, flexible, and carried out in learning activities and the formation of student competencies. (3) Activities arranged and developed in teaching preparation need to be supported following the established competencies. (4) The developed teaching preparation needs to be complete and comprehensive, with clear achievements. (5) There needs to be coordination between the components of implementing school programs, assuming the learning is carried out in teams or moving classes moving class (Mulyasa, 2004). The planning referred to is the preparation of the curriculum which is then integrated into the educational calendar, semester program, RPPM, and RPPH.

As a term, making a plan is part of success. Careful planning arranged into learning tools by incorporating values character in curriculum development. The curriculum is the key to the successful implementation of 
education character in the 2013 early childhood curriculum. Related to the preparation curriculum, this planning is carried out by all teaching staff and education personnel.

All components of the institution play an active role in instilling the character of students. Therefore, all parties need to work together by activating communication with one another directly or indirectly (Whatsapp group). Communication is an activity that is always carried out by everyone because it is needed for humans as social beings. It is the heart of life in organizations, the key to successful team effort (Suriansyah, 2014).

The implementation of character planting is carried out by all components of the institution, starting with the example and starting from simple things and carried out continuously every day. Exemplary is the most absolute element to do changes in life behavior, in preparing and forming children's spiritual and social morals. Therefore, the best example in the view of the child to be imitated in behavior and his manners are etched in juwa. This example is appropriately used to instill children's character and social values. That is, advice that is not accompanied by exemplary like the proverb brings sea salt to marinate the sea, more work is wasted than the benefits. Habituation, in essence, contains experience. Habit is something that is practiced. Therefore, the essence of habituation is repetition.

According to the Ministry of National Education (2010), character education is everything something the teacher does, which can influence character learners. Psychologically and socially culturally the formation of character in an individual is a function of the full potential of the human individual (cognitive, affective, connective, and psychomotor) in the context of socio-cultural interactions (in family, school, and community) and lasts a lifetime. Evaluation of 2013 Curriculum learning related to the implementation of character education on sites 1 and 2 is conducted on a daily, weekly, and monthly basis, before the end of the semester with the distribution of student report cards. These progress reports are independently carried out by the teacher, based on daily notes in the contact book and anecdotes. Both sites also provide simple rewards, as a form of teacher appreciation to students for their efforts to be better in all aspects.

The evaluation includes various steps, namely data collection on children's development and learning, determining the importance of the program in considering program objectives, incorporating information into plans, and presenting findings. Assessment of children's progress is integrated with the curriculum and teaching. In the PAUD program, various procedures are used to (1) Design instructions for each child and group. (2) Communicate with the child's family. (3) Identifying children that need special treatment or intervention. (4) Informing the development of the program (Santi, 2009).

On-site 1, the task was evaluated by the deputy head of the curriculum to lead and subsequently conduct supervision and coach the preparation of learning tools. While on-site 2 , it is called the curriculum team with a similar task as site 1 .

The cross-site data analysis results are seen in the following explanation. This research has presented findings data in the PAUD Islam Terpadu Al Khair Barabai and Negeri Pembina Barabai. To conduct a cross-site analysis, the researcher explained the conclusions of the propositions from both sites.

\section{Proposition conclusions of site 1}

Based on the results of interviews, observations, and documentation, conclusions were drawn on the character values implemented by PAUD Islam Terpadu Al Khair on the Graduate Competency Standard of the Integrated Islamic School Network. The character education which integrates the values of the government and Islamic values becomes the basis of informing the vision, mission, goals, and curriculum of the institution. Educational Institutions aim to graduate children with character, to pilot education institutions using the Integrated Islamic School Network. The curriculum is integrated through programmed and habituation activities such as RPPM which include KI, KD, and SKL from JSIT. RPPH uses the $5 \mathrm{M}$ method which consists of observation, asking, information gathering, reasoning, and communication following the 2013 Curriculum and TERPADU 
which explains, explores, responses, habituates, affirms, worldly, and ukhrawi, following SKL of JSIT. The habituation activities consist of SOP, Liaison Book, Memorandum Syllabus, spontaneous activities which consist of students, educators, spatial planning, dress banners Muslims, non-smoking area banners, and the existence of institutional culture. The JSIT distinctive curriculum emphasizes religious values as a basis for the cultivation of children's character, such as research on the religionbased model implemented by Islamic schools which shows that all components including parents carry out religious-based character education, thereby, making it a real example for all students (Celia, Suriansyah \& Asniwati, 2018)

When a child has Islamic characteristics with a foundation of faith they tend to learn how to respect other people, irrespective of their religion. Teachers added the following strategies to expand tolerance in children, namely (1) good characters, 2) nature of religious tolerance; (3) a stimulus for the child to think of good qualities; 4) provides a stimulus for religious tolerance, 5) makes the child feel its benefits (Zain, Saleh \& Noorhapizah, 2018).

Character values that are implemented based on the JSIT curriculum are faith, piety, manners, love of God, Apostles, Prophets, Companions of the Prophet, Pillars of Faith, and Islam. Besides, the character values implemented are as follows: religious, honest, tolerance, discipline, hard work, creative, independent, democratic, curiosity, national spirit, love of the motherland, valuing achievement, being friendly/communicative, peace-loving, fond of reading, caring for the environment and society. KI-1 consists of the following Spiritual Attitude: observance of worship, gratitude, praying before and after activities, and tolerance. While $\mathrm{KI}-2$ consists of the following social Attitudes: honesty, discipline, responsibility, politeness, caring, confidence, cooperation, accuracy, diligence, and others following competencies in learning.

Strategies used in the Implementation of Character Education of PAUD Islam Terpadu Al Khair is carried out by all teaching staffs including foundations, heads, educators, students, and parents through planning, implementation, and evaluation. Planning is a form of effort used to compile a curriculum managed by the deputy's head in the form of a set of learning including RPPM, RPPH, and SOP. Besides, its implementation requires synergy from all components of the institution to achieve educational goals to the maximum. The evaluation forms also vary for students in the form of anecdotal records, daily, weekly or monthly assessments and reported to parents through contact books and report cards.

\section{Proposition conclusions of site 2}

Character values implemented by PAUD Negeri Pembina are sourced from the 2013 Curriculum. It is the basis for forming the vision, mission, goals, and curriculum of the institution. The purpose of PAUD Negeri Pembina's education is to develop the ability of knowledge, skills, spiritual, social, and emotional for children to acquire a bright future.

The 2013 curriculum which is integrated through programmed activities and habituation activities was used. This consists of programmed activities such as RPPM which include $\mathrm{KI}$ and KD. While RPPH uses the 5M method which consists of observation, asking questions, gathering information, reasoning, and communication. The habituation activity consists of routine (SOPs, Liaison Books), spontaneous (reminding students, giving appreciation), exemplary (all education staff), conditioning (spatial planning), and the existence of institutional culture activities (5S, religious tolerance).

The character values implemented are religious, honest, tolerance, discipline, hard work, creative, independent, democratic, curiosity, national spirit, love of the motherland, valuing achievement, friendly/communicative, loving peace, fond of reading, environment, and social responsibility. The 2013 curriculum consists of $\mathrm{KI}-1$ and KI-2, where KI-1 is the Spiritual Attitude which consists of observance of worship, gratitude, praying before and after activities, tolerance in worship. KI-2 comprises of Social Attitudes as follows: honesty, discipline, responsibility, politeness, caring, confidence, cooperation, accuracy, perseverance, and others 
following competencies in learning. Character education in PAUD Negeri Pembina is carried out by all teaching and educational staff including students and parents, using the planning, implementation, and evaluation strategy.

Planning is an effort used to compile a curriculum in the form of a set of learning such as RPPM, RPPH, and SOP. It is also managed by the curriculum team.

Its implementation requires synergy from all components of the institution to achieve educational to the maximum.

The evaluation forms which also vary for students are in the form of anecdotal records, daily, weekly or monthly assessments and reported to parents through contact books and report cards.

\section{Cross-site analysis}

Cross-site analysis in this research is based on the results of the above research findings. The implementation of early childhood character education from the perspective of the 2013 curriculum in the PAUD Islam Terpadu Al Khair Barabai and Negeri Pembina Barabai shows a change in the character planting of children. Especially when the institution combines the 2013 curriculum with the character with changes and updates to the concept or outlook on education. Important points are obtained for young children based on Islamic values. After determining the basic competencies of the 2013 curriculum, another important component of Islamic values were added to the advantage of PAUD Islam Terpadu Al Khair Barabai.

As earlier explained, the nature of implementing the curriculum results and quality changes in student learning fit the educational goals. This means that curriculum implementation is a process of change to obtain results that are close to achieving the ideal educational goals. Therefore, all curriculum work, from the design, implementation, and evaluation is a cycle of change (Ansyar, 2015).

Therefore, this cross-site analysis produces the following:

Character values implemented by the PAUD Islam Terpadu Al Khair are sourced from the 2013 Curriculum and the Graduation Standards for the Integrated Islamic School
Network. Character education which integrates the values of the government and Islamic values becomes the basis of informing the vision, mission, goals, and curriculum of the institution. Educational Institutions aim to graduate children with good characters to pilot education institutions.

The curriculum used is the 2013 Curriculum is from the Integrated Islamic School Network and integrated through programmed and habituation activities. The programmed activities such as RPPM include KI, KD, and SKL from JSIT. While the RPPH used the 5M methods which consist of observation, asking questions, gathering information, reasoning, and communicating, which is following TERPADU consisting of explanation, exploration, response, habituation, affirmation, worldly and ukhrawi following SKL of JSIT. The habituation activities consist of routine (SOP, Liaison Book, Habituation Book, Memorandum Syllabus), spontaneous (reminding students, giving appreciation), exemplary (from all educators), conditioning (spatial planning, dress banners Muslims, non-smoking area banners) and the existence of institutional culture activities). Character values implemented by PAUD Negeri Pembina are sourced from the 2013 Curriculum which is the basis for forming the vision, mission, and institutional goals. The purpose of PAUD Negeri Pembina's education is to develop knowledge, spiritual, social, and emotional skills for children to acquire a bright future.

The 2013 Curriculum which is integrated through programmed activities and habituation activities was utilized. Programmed activities such as RPPM include $\mathrm{KI}$ and KD. Where RPPH uses $5 \mathrm{M}$ which consists of observation, questioning, gathering information, reasoning, and communication. The habituation activities consist of routine (SOPs, Liaison Books), spontaneous (reminding students, giving appreciation), exemplary (from all educators and education staff), conditioning (spatial planning), and the existence of institutional culture activities (5S, religious tolerance). Character values are applied based on the 2013 Curriculum and the development of culture created by the Ministry of National Education. However, more character 
values are applied in the PAUD Islam Terpadu $\mathrm{Al}$ Khair Barabai, in addition to the above mentioned that are sourced from the SKL of JSIT which is a curriculum characteristic of the institution. The character values are JSIT which comprises of Faith and piety, manners, love of God, Apostles, Prophets, Companions, Pillars of Faith and Islam. Besides, the character values are religious, honest, tolerance, discipline, hard work, creative, independent, democratic, curiosity, national spirit, love of the motherland, respect for achievement, friendship/communication, peace, love to read, care for the environment and social responsibility. KI-1 Spiritual Attitude includes: observance of worship, gratitude, praying before and after activities, tolerance in worship. While the KI-2 Social Attitudes consists of honesty, discipline, responsibility, politeness, care, confidence, cooperation, accuracy, perseverance, etc.

Character education in the PAUD Islam Terpadu Al Khair Barabai and Negeri Pembina Barabai is carried out by all teaching and education staff including students and parents using the planning, implementation, and evaluation strategy.

Planning is an effort to compile a curriculum in the form of a set of learning including RPPM, RPPH, and SOP. This is managed by the deputy's head called the curriculum team with both sides conducting the implementation, demands, and components value for educational goals to be achieved. Similarly, in the evaluation stage, the two sites also carry out various forms of analysis for students in the form of anecdotal records, daily, weekly and monthly assessments which are reported to parents as contact books and report cards.

\section{Conclusion and Recommendation}

Based on the discussion of character implementation in education using the 2013 Curriculum in the PAUD Islam Terpadu Al Khair and the Negeri Pembina, the following conclusions are obtained:

In the implementation of character education, the 2013 Curriculum is used as a reference for the preparation of activities consisting of programmed activities and habituation activities for each institution.
The implemented character values are faith and piety, manners, love of God, Apostles, Prophets, Companions, Pillars of Faith, and Islam. Furthermore, the character values implemented are as follows: religious, honest, tolerance, discipline, hard work, creative, independent, democratic, curiosity, national spirit, love for motherland, valuing achievement, friendly, peace-loving, fond of reading, caring for the environment, and social responsibility. Besides, the 2013 Curriculum consists of KI-1 comprises of Spiritual Attitude such as observance of worship, gratitude, praying before and after activities, tolerance in worship. While KI-2 comprises Social Attitudes such as honest, discipline, responsibility, politeness, caring, confidence, cooperation, accuracy, perseverance, and others following competencies in learning. The character value implemented is determined by the curriculum used.

The strategy used in the Implementation of Character Education of PAUD Islam Terpadu Al Khair is carried out by all teaching and educational staff including the Foundation, heads, students, and parents, using the planning, implementation, and evaluation strategies.

Suggestions for educational institutions are to further develop and improve the implementation of the 2013 Curriculum in instilling the character of students. All components of the institution including parents must work together to support the vision, mission, and goals of the educational institution unit by starting with an example that is consistent in all aspects of daily life from even the smallest things.

\section{Acknowledgment}

The authors are grateful to the head of the study program and the secretariat of Masters in Teacher Education of Early Childhood Education, PAUD IT Al Khair Barabai, and Pembina Barabasi. In addition to the prayers and support of friends and loved ones, may Allah Subhanahu Wa Ta 'ala give more kindness to yours. Jazakumullahu khairan.

\section{References}

Ahmad, K. (2014). Penerapan pendidikan karakter, pendekatan SESOSIFIT (spiritual, emosional, sosial, intelektual, fitrah) melalui layanan bimbingan dan konseling. Tarbiyah Jurnal 
Ilmiah Pendidikan, 3(1), 45-49. Retrieved from http://eprints.unlam.ac.id/id/eprint/277

Ansyar, M. (2015). Kurikulum: Hakikat, Fondasi, Desain \& Pengembangan. Jakarta: Kencana.

Arsyad, A. (2010). Strategi implementasi pendidikan karakter bangsa di perguruan. Bogor: Balitbangdiknas.

Brandsford, J., \& Darling, H. (2005). Preparing teachers for a changing word: what teachers should learn. San Fransisco: CA: Jossey-Bass.

Celia, C., Suriansyah, A., \& Asniwati. (2018). The model of religion-based character education (multi-site integrated islamic PAUD Sabilal Muhtadin and PAUD islam Mawaddah Banjarmasin, Indonesia). European Journal of Education Studies, 3(7), 1-13. Retrieved from https://www.oapub.org/edu/

Gardner, H. (2006). Five minds for the future. Boston: Harvard Business School Press.

Kemendiknas. (2011). Panduan pelaksanaan pendidikan karakter. Jakarta: Badan Penelitian dan Pengembangan. Pusat Kurikulum dan Perbukuan.

Lickona, T. (2008). Educating for character how our school teach respect and responsibility. New York: Bantam Books.

Megawangi, R. (2017). Menyemai benih karakter. Depok: Indonesia Heritage Fondation.

Metroyadi. (2017). Upaya Mengembangkan Aspek Nilai-Nilai Agama dan Moral dalam Membedakan Perbuatan Baik dan Buruk Menggunakan Model Examples Non Examples dengan Variasi Media Audio Visual pada Anak Kelompok B di TK Aisyiyah Bustanul Athfal 31 Banjarmasin. Sagacious Jurnal Ilmiah Pendidikan dan Sosial, 4(1), 7-12.

Miles, M. B., Huberman, A. M., \& Saldana, J. (2014). Qualitative Data Analysis A Methods Sourcebook. USA: Sage Publications.

Mulyasa. (2004). Menjadi guru profesional. Bandung: Remaja Rosdakarya.

Poernamawijaya, L., Sulaiman, Suriansyah, A., \& Dalle, J. (2018). Contribution on supervision of supervisor, principals motivation, kindergarten teacher performance to improving the kindergarten quality in west Banjarmasin, Indonesia. European Journal of Alternative Education Studies, 3(2), 129-146.

Safitri, M. E. (2018). Development of Child Independence Through Model Picture and Picture, Examples Non
Examples Model and Practical Method Directly Activities of Learning Practical Life in Group B Kasih Ibu Kindergarten, Banjarmasin, Indonesia. European Journal of Education Studies, 5(7), 64-80. Retrieved from https://www.oapub.org/edu/

Salasiah, Asniwati, \& Effendi, R. (2018). Instilling Character Values in Early Childhood in The Perspective of Curriculum and Parenting (Multi-Site Study in PAUD Islam Sabilal Muhtadin and PAUD Mawaddah, Banjarmasin, Indonesia). European Journal of Education Studies, 5 (7)., 41. Retrieved from

https://oapub.org/edu/index.php/ejes/article/view/210 $\underline{0 / 4736}$

Santi, D. (2009). Pendidikan Anak Usia Dini: Antara Teori dan Praktik. Jakarta: Indeks.

Sudaryanti. (2012). Pentingnya pendidikan karakter bagi anak. Jurnal Pendidikan Anak, 1(1), 11-20. doi: https://doi.org/10.21831/jpa.v1i1.2902.

Sugiyono. (2017). Metode penelitian kualitatif: untuk penelitian yang bersifat eksploratif, enterpretif, interaktif dan konstruktif. Bandung: Alfabeta.

Suhaimi \& Rinawati, Y. (2018). Management of Character Education Curriculum at Vocational High School 2 Kandangan. Advances in Social Science. Educational and Humanities Research, 272-274. doi:https://doi.org/10.2991/iccite-18.2018.59

Sukriani, Huda A. Y. M., Arifin, I., \& Suriansyah, A. (2017). The Implementation of The Islamic Schools Resources Total Quality Management in Banjarmasin, Indonesia. Journal of Social Sciences (COES\&RJ-JSS), 6(1), 125-138.

Suriansyah, A. (2014). Hubungan Budaya Sekolah, Komunikasi, dan Komitmen Kerja Terhadap Kinerja Guru Sekolah Dasar Negeri. Cakrawala Pendidikan, 358-367.

Suriansyah, A. (2015). Strategi Kepemimpinan Kepala Sekolah, Guru, Orangtua dan Masyarakat dalam Membentuk Karakter Siswa. Cakrawala Pendidikan, Th. XXXIV, No. 2, 234-247.

Zain, A., Saleh, M., \& Noorhapizah. (2018). Strategy for the Development of religious worship and religious tolerance at Widya Dharma PAUD in Banjarmasin City, Indonesia. European Journal of Education Studies, 3(2), 88-106. Retrieved from https://www.oapub.org/edu/ 